\title{
The Effect of Anthropomorphic Appeal on Consumer Protective Behavior in Service Facilities
}

\author{
Dwinita Laksmidewi \\ Faculty of Economics and Business, Universitas Katolik Indonesia Atma Jaya, Jakarta, Indonesia \\ Email Adress: \\ dwinita.laksmi@atmajaya.ac.id
}

\begin{abstract}
Implementing health protocols, wearing masks, and maintaining physical distance in the service facilities are necessary during this Covid-19 pandemic. So, we need a health appeal message in the service industry to discipline consumer behavior. This study examines the effects of anthropomorphic persuasive appeal on consumer protective behavior. This study consists of two studies and used an experimental method. The results showed that the anthropomorphic persuasive message made consumers feel more fear, understand the message more easily, and perceive that the object had more power. The effect of messages on protective behavior is significantly mediated by fear. Meanwhile, ease of understanding and power are not significant mediations. Study 2 which focuses on the application in service facilities also shows that anthropomorphic appeal can influence protective behavior. These results indicate that the emotional aspect, in this case, the fear of consumers, has more influence on protective behavior.
\end{abstract}

Keywords: anthropomorphism, fear, protective behaviour.

\begin{abstract}
Abstrak: Penerapan protokol kesehatan, memakai masker, dan menjaga jarak fisik di fasilitas pelayanan sangat diperlukan selama pandemi Covid 19 ini. Maka, diperlukan pesan himbauan kesehatan pada industri jasa untuk mendisiplinkan perilaku konsumen. Penelitian ini menguji pengaruh pesan antropomorfik terhadap perilaku protektif konsumen. Penelitian ini terdiri dari dua studi dan menggunakan metode eksperimen. Hasil penelitian menunjukkan bahwa pesan himbauan persuasif antropomorfik membuat konsumen lebih merasa takut, lebih mudah memahami dan mempersepsikan objek memiliki kekuatan yang lebih besar. Pengaruh pesan pada perilaku protektif secara signifikan dimediasi oleh rasa takut. Sedangkan kemudahan pemahaman dan kekuasaan tidak menjadi mediasi yang signifikan. Studi 2 yang berfokus pada aplikasi di fasilitas jasa juga menunjukkan bahwa himbauan antropomorfik dapat berpengaruh terhadap perilaku protektif. Hasil tersebut menunjukkan bahwa aspek emosional dalam hal ini perasaan takut konsumen lebih berpengaruh terhadap perilaku protektif.
\end{abstract}

Kata kunci: antropomorfisme, perasaan takut, perilaku protektif.

\section{INTRODUCTION}

$\mathrm{Hi}$, my name is Covid-19. This sentence opens the story booklet issued by the Ministry of Women's Empowerment and Child Protection of the Republic of Indonesia in 2020 to 
introduce Covid-19 to children. In this booklet, the Coronavirus is told by conveying as if he (Coronavirus) is a human. I am good at jumping, you know! This sentence borrows a term from human activity (jump). We also hear or see in the media that this virus is illustrated in human terms "enemy, evil, and smart". Coronavirus "doesn't care" who you are, whether you are rich or poor, old or young, smart or not. Previous research shows that educational programs regarding protected animals delivered anthropomorphically can increase student knowledge (Kamil et al., , 2019).

Our tendency to give human characteristics to animals or non-human objects is called anthropomorphism (Epley et al., 2007). The use of anthropomorphism makes something difficult easier to understand (Guthrie, 1995). Anthropomorphism narrative provides a familiar model of something confusing and completely uncertain, because the most familiar model is us (Guthrie, 1995).

The Ministry of Health has issued a health protocol rule for the public in public facilities to prevent Covid-19. These public facilities include shopping centers, malls, shops, hotels, restaurants, transportation facilities, sports facilities, tourist attractions, and places of worship. Consumers who visit these public facilities are obliged to ensure that they are healthy, must wear masks, and keep their distance. However, until this research was conducted there were still many consumers who had not complied with the health protocol in public facilities. From the data from the Covid-19 handling task force as of March 3, 2021, there were as many as 15 million people who were reprimanded in public facilities for not complying with health protocols, during February 21-28, 2021 (https://databoks.katadata.co.id/). This fact is quite concerning because the government announces that positive cases of Covid-19 are still increasing, while not all people have been vaccinated.

Facing a situation where consumers are not fully willing to comply with health protocols, it is necessary to make efforts to raise consumer awareness. Several world-class brands, such as McDonald's, Coca-Cola, Audi, and Volkswagen have redesigned logos and messages that promote social distancing. This social distancing logo is intended to help and educate consumers, as a social distancing movement that seeks to reduce the severity of the Covid-19 pandemic (https://edition.cnn.com/2020). In the service industry, research on anthropomorphism associated with social distancing is carried out as in Ali, Dogan, Amin, (Hussain and Ryu, 2021) which examines the effect of brand anthropomorphism on brand love and brand defense. This influence differs between consumers who are positive about social distancing and consumers who are negative.

This study aims to determine the effect of applying anthropomorphism to the Covid19 message on consumer health protocol behavior (protective behavior). The application of anthropomorphism here is to give the Coronavirus human-like characteristics. (Guthrie, 1995) explained that anthropomorphism makes the difficult ones easier to understand. So, giving the coronavirus human-like characteristics is one way to make it more understandable. However, people are more likely to understand and predict humans than non-human objects (Waytz et al., 2010). In this study, messages that increase understanding of the coronavirus and see it as a strong but evil virus are expected to affect behavior in adopting health protocols, namely wearing masks and maintaining distance. To increase understanding of the Coronavirus, we use an anthropomorphic approach, which is to give human characteristics to the Coronavirus. 
During this pandemic, both print and online media describe the Coronavirus in various forms. Cartoonists represent the uniqueness of the Coronavirus in visual rhetoric using color, morphological characteristics, and anthropomorphism (Joubert and Wasserman, 2020). Viruses are usually green or red and are associated with Human characteristics, most often a malevolent-looking facial expression and with an exaggerated spiny trunk. Of the 120 pictures of the Coronavirus, more than half are illustrated anthropomorphically, and the dominant emotion of the Coronavirus pictures is the emotion of fear (Joubert and Wasserman, 2020). Experts use anthropomorphic terminology for viruses and so do ordinary people interpret it anthropomorphically (Kutschera, 2020).

Previous research has shown that consumers perform protective behavior depending on temporal construal focus, namely whether consumers focus on the present or the future (Wan et al., 2020). Individuals tend to perform protective behaviors such as wearing masks and gloves if they tend to focus on the present. According to (Wan et al., 2020), the coronavirus is an anthropomorphic language that increases protective behavior, relative to consumers who have a focus on the present. As well as research by (Wan et al., 2020) in this study, an experiment was carried out on Indonesian consumers, looking at the effect of anthropomorphic Coronavirus messages on health protocol adoption behavior. We add a mediating effect to feelings of fear. By better understanding, the crimes of the coronavirus will affect feelings of fear of Covid-19, which will then affect the willingness of consumers to carry out health protocols.

\section{THEORETICAL REVIEW}

Anthropomorphism. Anthropomorphism is defined as the tendency to perceive humanlike characteristics in real or imagined non-human agents (Epley, Waytz \& Cacioppo, 2007). These human-like characteristics can include physical appearance (eg, religious agents believed to look human), emotional states that are uniquely human, or mental states and motivations. Real or imagined non-human agents can be anything that acts - or is believed to be acting - with visible independence, including animals, natural forces, religious agents, technological gadgets, or mechanical devices (Epley et al., 2007).

According to (Guthrie, 1995), there are at least two things that underlie why anthropomorphism occurs. First, namely familiarity thesis, anthropomorphism allows us to explain things that we don't understand by using things that we understand because the best we understand is ourselves. Secondly, the comfort thesis is that we feel uncomfortable with things that are not like us, so making things the way we are making us feel good. (Guthrie, 1995) says that we are in perceptual uncertainty, which is the result of our insecurity and inability to predict or control the environment. It makes us always try to understand the situation through imagination. Most people cannot see so carefully; they can only think about unknown causes in a common and confusing way through imagination. In anthropomorphism, we imagine non-human objects in human form, characteristics, and emotions. This enables us to predict and control the environment.

According to (Epley et al., 2007), a person cannot know what it feels like to be an animal (or another being), because human sensory experience is in himself. Knowledge about human experience is experienced directly, so it is easier, more complete, and faster than another knowledge. Humans face situations where there is always uncertainty in their environment. During this pandemic, consumers who are unfamiliar with the virus feel 
uncertainty and the Coronavirus cannot be predicted. Under what conditions do we attribute human likeness to nonhumans? (Disalvo and Gemperle, 2003) provide several conditions given to non-human objects that can encourage anthropomorphism, namely: Having a human face, physical appearance, and social behavior, e.g., social behavior. Shake his head; social context cues, e.g., naming objects after people; social interaction, e.g., we blame an animal or object as if it did something wrong; relationships or possession; and personality.

Alienation due to uncertainty, and the importance of predicting the behavior of nonhuman agents (in this case the Coronavirus), affects a person's tendency to anthropomorphize these non-human agents (Epley et al., 2008). Anthropomorphism allows a person to interact effectively with nonhuman agents and increases the ability to interpret agent actions, reduces agent uncertainty, and increases confidence in predicting these agents in the future. Furthermore, according to Epley et al. (2008) anthropomorphism can be a way to direct one's behavior towards unknown agents or stimuli. Epley et al. This factor is termed as effectance motivation, in his theory "Three-factor theory of anthropomorphism".

The Waytz, Morewedge, Epley, (Monteleone and Cacioppo, 2010) study shows that increasing effectance motivation by manipulating unpredictable non-human agents will increase anthropomorphism. So, in this study, the Coronavirus as a non-human agent will be manipulated into having human characteristics, to reduce uncertainty and increase the perception of the ability to predict this virus in the future. The Waytz et al. using non-human agents, gadgets, and dogs, also showed that increased effectance motivation can also make people more able to understand non-human agents. According to (Waytz et al., 2010) Uncertainty is the basic trigger for prediction and control. Uncertainty increases sense perception by triggering motivation to understand, predict, and control, as well as a lack of personal control.

Easiness. Human cognitive capacity is limited so that people often take shortcuts to reduce effort. In some situations, we can grasp information with our senses and process it automatically, effortlessly, and involuntarily. When we try to process so much social information at one time, we will again try to use existing schemes because this framework helps us process information with less effort (Zhu et al., 2011). The human schema is the knowledge that already exists before another knowledge and therefore makes understanding the coronavirus easier if this virus is described in a human schema.

Research on anthropomorphism has the effect of anthropomorphism on convenience. In the current era of information technology, the use of anthropomorphic chatbots is easier to adopt because they imitate human services, so they are considered easier to use (Sheehan et al., 2020). Consumers overestimate the chatbot's abilities and are then disappointed or frustrated when those expectations are violated. Chatbot errors result in decreased anthropomorphism and reduce chatbot use (Sheehan et al., 2020). Technological anthropomorphism also helps reduce consumer dissatisfaction after a service failure (Fan et al., 2019). This is moderated by interdependent self-construal and technology self-efficacy. Comparing with our world makes us more understandable, so anthropomorphic delivery is easier to understand on something that consumers as ordinary people do not really understand, such as disease caused by Coronavirus.

H1: Illustrating the Coronavirus with a human scheme (Corona anthropomorphic) makes it easier for consumers to understand. 
Fear. The Covid-19 pandemic is having an impact on social behavior. The Covid-19 pandemic is considered a threat, which causes fear, anxiety, a feeling of uncertainty (Ling and Ho, 2020). The rational individual can be selfish and opportunistic, prioritizing his own interests for short-term gain, and at the same time thinking of the collective interest. Take panic buying behavior at the start of a pandemic, for example.

Feelings of fear are included in negative emotions, which are often caused by threats (Dedeoglu and Ventura, 2017). In the current pandemic situation, the threat is suffering and death from the COVID-19 virus, both for oneself and for family members. Negative emotions due to COVID-19 include anger, disturbance, anxiety, depression, disgust, fear, frustration, sadness, hatred, hopelessness, loneliness, panic, anger, regret, annoyance, and shock (Huang, 2020). Although fear and anxiety are negative emotions, not all negative emotions are bad; for example, fear and worry can lead people to take precautions (Huang, 2020). These negative emotions are included in a rational level, following a situation that encourages prevention efforts, to keep people safe (Huang, 2020). In the Covid-19 pandemic situation, this rational fear encourages protective action, namely being willing to carry out health protocols, wearing masks, and maintaining distance.

Consumers who are unfamiliar with the coronavirus need to understand so that rational negative emotion can encourage them to take protective behavior. An anthropomorphic approach to messages will create an easier and more familiar understanding. Everyone, in general, has knowledge and experience of human personality and actions. When people anthropomorphize an object that is not understood, it will increase their ability to understand that object. In addition, anthropomorphism will encourage people to respond to objects more emotionally (Wan and Chen, 2021). Emotional is meant here in the form of positive and negative emotions such as comfort, pleasure, emotional security, passion, happiness, vitality, discomfort, anxiety, and fear (Wan and Chen, 2021).

Advertising using the appeal of fear has been widely used, messages that remind consumers of God cause feelings of fear (Wu and Cutright, 2018). If anthropomorphism object supports people's needs, it will increase positive feelings. However, if the object of anthropomorphism imposes a threat to human needs, it will distance people from the object which is marked by negative feelings (Wan and Chen, 2021).

H2: Illustrating the coronavirus with the human scheme (corona anthropomorphic) increases consumers' fear of the effects of the virus.

Perceived Power. Research by Anderson and (Galinsky, 2006) shows that feelings of power increase a sense of optimism about risk. According to them, power makes people more optimistic to win, and avoid disease. In research on anthropomorphism, it is proven that power affects. People with high power perceive a lower risk of anthropomorphic objects, whereas people with low power perceive a higher risk of anthropomorphic objects, which then affects the desire to use the product (Kim and McGill, 2011). Likewise, in the study of (May and Monga, 2014), encouraging consumers to anthropomorphize waiting time has succeeded in making waiting time perceived as unpleasant, pleasant, or profitable for low power consumers. In this study, consumers will perceive the risk of anthropomorphic objects (anthropomorphic corona) being higher than objects (nonanthropomorphic) and then affect protective behavior. The study of (Wan et al., 2020) found 
that anthropomorphization of an agent, especially a negative agent, will make the agent appear more powerful and can affect how willing consumers are to act against this agent.

Protective Behavior. In (Mat et al., 2021) the argument is stated that individual behavior in adopting protective behavior is more important than government action in controlling the spread of COVID-19. Human behavior is paramount to tackle a pandemic. Someone will adopt protective behavior when they feel a high risk of infection and understand the severity of the disease. The problem is how people can understand the risk of this disease so that they intend to adopt protective behavior. They proposed the importance of the role of communication from both the government and social media to influence consumer attitudes towards protective behavior engagement. The study we conducted was related to communication aimed at influencing protective behavior engagement and in Study 1 we raised the risk of disease in the content of communication messages.

Anthropomorphic manipulated objects proved to have a positive effect on the brand outcome. In this pandemic, (Faizan et al., 2021) shows that using an anthropomorphic approach to brands has a significant effect on consumer love for the brand itself, moderated by attitudes towards social distancing consumers who support, and practice social distancing are individuals who emotionally motivated to distance themselves, so they tend to engage with anthropomorphic brands that are more human-like. On the other hand, consumers who have negative attitudes towards social distancing may be more individualistic, so that brand anthropomorphism may not influence them. In addition, brand anthropomorphism also has a positive effect on brand trust and brand commitment (Golossenko et al., 2020).

Previous research has shown that anthropomorphic objects have a positive effect on consumer behavior. (Zhou et al., 2019) study shows that when participants interpret money as people with human-like characteristics rather than as mere objects, they are not only more likely to donate money but also donate more money. Anthropomorphism and future messages have a significant positive effect on consumer purchase intentions of bad food (Shao et al., 2020). Likewise, (Wan et al., 2020) suggests that the anthropomorphic message of coronavirus affects protective behavior.

At service centers, the application of physical distancing during a pandemic is very important. The use of negative framed suggestions will be very useful for consumers to be willing to comply. The (Khoa et al., 2021) in their research offer negative framed message delivery with anthropomorphism. The use of visual and verbal anthropomorphic persuasion, such as replacing the term coronavirus with the deadly Mr. COVID-19, adding the scary face of the coronavirus, can persuade consumers to keep their distance.

H3: The anthropomorphic coronavirus has a significant effect on the willingness of consumers to carry out health protocols at the service place (wearing masks and maintaining distance/protective behavior), mediated by fear (H3a), easiness $(\mathrm{H} 3 \mathrm{~b})$, and power $(H 3 c)$.

H4: Anthropomorphic appeal has a significant effect on consumer protective behavior, mediated by fear $(\mathrm{H} 4 \mathrm{a})$ and easiness $(\mathrm{H} 4 \mathrm{~b})$.

Study 1. Study 1 aims to test hypotheses 1-3. In this study, the information conveyed to consumers is difficult information, namely about the Coronavirus disease. In the 
manipulation group, information is conveyed using an anthropomorphic approach, which aims to test whether the message is easier to understand.

\section{METHOD}

The study used an experimental method, with 2 groups: anthropomorphic vs. object, between participants. The stimulus is in the form of text and image messages, adapted from (Wan et al., 2020). In anthropomorphic conditions, the message image is a visual form of the red coronavirus which has creepy eyes, a prickly body, a mouth with grinning fangs, is chasing a masked globe crying in fear. Texts using human designations include "they, sneaky murderers, members of criminals, evil little assassins, trained killers" for the Coronavirus, with verbs including sneak, target, send orders. While the virus group stimulus as an object, uses the visual of the red coronavirus, without human physical attributes, continues to use the term coronavirus, and explains how the virus works, for the same thing as the manipulation group, but without a verb/human. A total of 67 participants aged 19-24 years, male and female, between the participants, were randomly grouped into the 2 groups.

The variable measured was the behavior of maintaining physical distance and maskwearing as the dependent variable which was adapted from The Khoa et al. (2021), physical distancing consists of 4 items $(\alpha=0.757)$, and mask-wearing consists of 6 items $(\alpha=0,906)$. A mediating variable is fear, measured by 3 items adapted from The Khoa et al. (2021) with $\alpha=0.886$; convenience consists of 3 items with $\alpha=0.896$. Anthropomorphism was measured with 3 items, as a manipulation check, adapted from Wan et al. (2020). Power consists of three items $(\alpha=0,775)$ adapted from (Wan et al., 2020). Power asked how severe the problem was, how strong and how far the impact of the Coronavirus in life. Meanwhile, easy consists of three items $(\alpha=0,896)$ that the researcher makes based on the conceptual basis of the benefits of anthropomorphism according to (Guthrie, 1995). The indicators include, among others, easy-to-understand and familiar messages. The data were processed using one-way Anova, and the SPSS Macro Hayes regression mediation test (Hayes, 2017).

\section{RESULTS}

Manipulation Check. To ascertain whether the stimulus that was made contained anthropomorphic manipulation, participants were asked questions measuring the extent to which the Coronavirus has its own intentions, has free will, and looks like humans. These three items were used by Kim and McGill (2011) to check for anthropomorphic manipulation. The results showed that the anthropomorphism of the two groups was significantly different $(\mathrm{F}=67.312 \mathrm{p}=0.000)$. The anthropomorphism group $\mathrm{M}=4.5859$ $(\mathrm{SD}=0.1479)$ was higher than the object group $\mathrm{M}=2.8922(\mathrm{SD}=0.14402)$. Thus, the manipulation is successful and can be used for further analysis. 
Table 1. ANOVA of Mediation Variables

\begin{tabular}{lcccc}
\hline \multicolumn{1}{c}{ Variables } & Mean & SD & F & sig \\
\hline Fear & & & & \\
$\quad$ Anthropomorphic & 4.4949 & 1.10906 & 6.478 & .013 \\
$\quad$ Object & 3.8627 & .91790 & & \\
Easiness & & & & \\
$\quad$ Anthropomorphic & 4.7475 & .73612 & 13.039 & .001 \\
$\quad$ Object & 3.9020 & 1.13271 & & \\
Power & & & & \\
$\quad$ Anthropomorphic & 5.2626 & .64419 & 12.370 & .001 \\
$\quad$ Object & 4.5294 & 1.01543 & & \\
\hline
\end{tabular}

Easiness. The message about the Coronavirus that is conveyed anthropomorphically, using human terms like them, a sneaky and skilled killer, makes the message easier to understand $(M=4.7475)$ when compared to if the virus is described as an object $(M=3.9020)$, with a significant difference $(F=13.039 p=0.001)$. Thus Hypothesis 1 is accepted (Table 1).

Fear. The effect of the Coronavirus in anthropomorphic messages, apart from using human terms, also acts as human and human-like intentions, able to make participants more afraid of this virus $(M=4.4949)$ than feeling afraid of the virus group as an object $(M=3.8627)$. The difference in feelings of fear between the two groups was significant $(F=6.478 p=$ 0.013). Then hypothesis 2 is accepted (Table 1).

Table 2. Protective behavior - physical distancing.

\begin{tabular}{lcc}
\hline \multicolumn{1}{c}{ Item } & Mean & SD \\
\hline I will avoid going to crowded areas when shopping & 4,3134 & 0,9724 \\
I will physically distance myself from other people while shopping. & 4,9701 & 0,9529 \\
I will keep a safe distance from people when shopping & 5,1940 & 0,8570 \\
I will keep myself from touching other people while shopping & 5,2985 & 0,7590
\end{tabular}

Protective Behavior. On a scale of six, protective behavior by maintaining a distance shows a high enough value (Table 2). Participants avoid crowds, maintain distance, distance themselves from other people, and guard against contact with other people while shopping. Of the 6 question items regarding mask-wearing on a scale of 1-10, the participants were most willing to wear a mask when walking in the mall $(M=7,1517)$, shopping in stores $(M=7,7313)$, and when on an airplane $(M=6,9701)$. Participants were somewhat less willing to wear masks when exercising in the gym $(M=5,3433)$. Meanwhile, when sitting in the cinema $(M=6,3433)$ and taking public transportation $(M=6,4478)$, the participants may wear masks.

Mediation tests. The results of hypothesis testing in Table 3 show that the explanation of the coronavirus anthropomorphically makes participants feel afraid $(t=2,5451 p=0,0133)$. This feeling of fear also has a significant effect on protective behavior $(t=6,5661 p=, 0000)$. 
Anthropomorphic messages have a direct and significant effect on protective behavior. $(t=3,7364 p=0,0004)$. Furthermore, the mediation test showed that the feeling of fear was a significant mediator $(a b=0.3083 S E=0.0580 L L C I=0.0580 U L C I=0.6749)$. Thus, hypothesis $3 \mathrm{a}$ is accepted.

Table 3. The Study 1 mediation results.

\begin{tabular}{|c|c|c|c|c|}
\hline Predictors & $\begin{array}{c}\text { Fear } \\
\text { B }(\mathrm{SE})^{\mathrm{a}}\end{array}$ & $\begin{array}{c}\text { Easiness } \\
\text { B }(\mathrm{SE})^{\mathrm{a}}\end{array}$ & $\begin{array}{l}\text { Power } \\
\text { B }(\mathrm{SE})^{\mathrm{a}}\end{array}$ & $\begin{array}{l}\text { Protective } \\
\text { Behavior }\end{array}$ \\
\hline \multicolumn{5}{|l|}{ Independent Variables } \\
\hline Anthropomorphic & $\begin{array}{c}0,6322 \\
(0,2484)^{*}\end{array}$ & $\begin{array}{c}0,8455 \\
(0,2342)^{* *}\end{array}$ & $\begin{array}{c}0,7332 \\
(0,2085)^{* *}\end{array}$ & $\begin{array}{c}0,6236 \\
(0,1669)^{* *}\end{array}$ \\
\hline Fear & & & & $\begin{array}{c}0,4877 \\
(0,0743)^{* *}\end{array}$ \\
\hline Easiness & & & & $\begin{array}{c}0,0263 \\
(0,0788)\end{array}$ \\
\hline Power & & & & $\begin{array}{c}0,1297 \\
(0,0983)\end{array}$ \\
\hline $\mathrm{R}^{2}$ & 0,3010 & 0,4088 & & 0,7594 \\
\hline \multicolumn{2}{|c|}{$\begin{array}{l}\text { Bootstrap indirect effects on protective } \\
\text { behavior (through fear and easiness) } \\
\text { b }\end{array}$} & B (SE) & LL $95 \%$ CI & UL $95 \%$ CI \\
\hline \multicolumn{2}{|c|}{ Anthropomorphic-Fear-Behavior } & $\begin{array}{c}0,3083 \\
(0,1586)\end{array}$ & 0,0580 & 0,6749 \\
\hline \multicolumn{2}{|c|}{ Anthropomorphic-Easiness-Behavior } & $\begin{array}{c}0,0222 \\
(0,0643)\end{array}$ & $-0,1205$ & 0,1357 \\
\hline \multicolumn{2}{|c|}{ Anthropomorphic-Power-Behavior } & $\begin{array}{c}0,0951 \\
(0,0814)\end{array}$ & $-0,0385$ & 0,2844 \\
\hline
\end{tabular}

Anthropomorphism makes it easy for people to understand, the results of this study show this. The explanation of the coronavirus delivered anthropomorphically has a significant effect on easiness $(t=3,6110 p=0,0006)$, however, this easier understanding does not have a significant effect on protective behavior $(t=0,3338 p=, 7396)$. Likewise, the mediation test shows that easiness is not a significant mediator in the effect of anthropomorphic messages on protective behavior $(a b=0.0222 S E=0.0643 L L C I=-$ $0.1205 U L C I=0.1357$ ). Then hypothesis $3 \mathrm{~b}$ is not supported.

Power makes people more optimistic and avoids disease. Anthropomorphic messages have a significant effect on perceived power $(t=3,5171 p=0,0008)$. Participants perceived the coronavirus as stronger, the problem with the coronavirus was severe and had an impact on life. However, the perception of power had no significant effect on protective behavior $(t=1,3194 p=, 1917)$. Likewise in hypothesis testing, power does not become a significant mediator $(a b=0.0951 S E=0.0814 L L C I=-0.0385 U L C I=0.2844)$. Thus, hypothesis $3 \mathrm{c}$ is not supported.

Study 2. The results of study 1 indicate that anthropomorphic messages have direct effect on protective behavior. This message creates more fear, and it is fear that affects protective behavior at service facilities. The direct effect in Study 1 is due to the content of the message 
which is not an appeal for protective behavior (physical distancing), but it is more about knowledge about Covid-19 which triggers feelings of fear in participants. We would like to retest this effect in the application in service facility, namely the message containing the appeal. Therefore, in Study 2 we constructed a message containing an appeal for physical distancing. In the manipulation group, the appeal for physical distancing uses anthropomorphic images. Study 2 aims to test hypothesis 4.

In Study 2 we used an experimental method, with two groups (Appeal: anthropomorphic vs. non anthropomorphic) between participants. 62 participants involved in this experiment, aged 19-35 years, 30 women and 32 men, assigned randomly into two groups. We constructed 2 images as stimuli, adapted from The (Khoa et al., 2020). This image is an appeal to maintain physical distance. In the picture there are two people, one man standing on the left, and one woman standing on the right, both are holding shopping bags. The image destined for the anthropomorphic appeal group contains a picture of the Coronavirus between the two people. Whereas in the image intended for the control group (non-anthropomorphic), there is a two-way arrow between the two people. The dependent variable is protective behavior measured using the same scale as Study 1 and the mediating variable is fear and easiness using the same measurement as Study 1. We used a one-way ANOVA to perform manipulation checks, testing the differences between group and control group manipulations for all study variables. Meanwhile, to test the hypothesis we use the bootstrapping mediation test.

Manipulation Check. We asked what the extent of the Coronavirus in the appeal poster looked like a human, to ascertain whether the stimulus that was made contained anthropomorphic manipulation. The results showed that the anthropomorphism of the two groups was significantly different $(F=11.336 p=0.002)$. The anthropomorphism group $M$ $=4.2000(S D=1.08012)$ was higher than the object group $M=3.0000(S D=1.38170)$. Thus, the manipulation is successful.

Table 4. ANOVA of Study 2 Variables

\begin{tabular}{lllll}
\hline \multicolumn{1}{c}{ Variables } & Mean & SD & F & sig \\
\hline Fear & & & & \\
$\quad$ Anthropomorphic & 4.7467 & .76546 & 23.070 & .000 \\
$\quad$ Non-Anthropomorphic & 3.6377 & .83432 & & \\
Easiness & & & & \\
$\quad$ Anthropomorphic & 5.0870 & .79275 & 2.276 & .138 \\
$\quad$ Non- Anthropomorphic & 4.7600 & .70887 & & \\
Protective behavior & & & & \\
$\quad$ Anthropomorphic & 5.2800 & .51194 & 18.811 & .000 \\
$\quad$ Non- Anthropomorphic & 4.5978 & .57771 & & \\
\hline
\end{tabular}

Fear, Easiness and Protective Behavior. Table 4 shows the results of the variable descriptions. Anthropomorphic appeal as in study 2, creates more fear $\left(M_{\text {antrop }}=4.7467 M_{\text {non- }}\right.$ ${ }_{A}=3.6377 F=23.070 p=0.000$ ), and the participants' intention to behave protectively in this group is higher $\left(M_{\text {antrop }}=5.2800 \quad M_{\text {non-A}}=4.5978 F=18,811 p=0,000\right)$. Between the anthropomorphic group and the control group, there were significant differences in fear and intention to behave protectively. In terms of ease of understanding, although the mean in the anthropomorphic group was higher, it did not show a significant difference 
$\left(M_{\text {antrop }}=5.0870 M_{n o n-A}=4.7600 F=2.276 p=0,138\right)$. In our opinion, this is because the appeal to maintain physical distance is quite easy for the participants to understand, in contrast to the knowledge about Covid 19 in Study 1 which is quite difficult for ordinary people to understand.

Mediation test. As with Study 1, in Study 2 we tested mediation using Macro PROCESS model 4 (Table 5). The results show that anthropomorphic appeal has a significant effect on feelings of fear $(t=4,8031 p=, 0000)$, but does not have a significant effect on easiness $(t=1,5085 p=, 1383)$. The anthropomorphic appeal has a significant direct effect on protective behavior $(t=2,9177 p=2,9177)$. Mediation tests show that anthropomorphic appeal influences protective behavior, mediated significantly by fear $(a b=0,2433 S E=$ $0,1247 L L C I=0,0264 \quad U L C I=0,5097)$. Meanwhile, the easiness variable did not significantly mediate the effect of anthropomorphic appeal on protective behavior $(a b=$ $0,0796 S E=0,0773 L L C I=-0,2818$ $U L C I=0,0106)$. Therefore, hypothesis $4 \mathrm{a}$ is accepted, while hypothesis $4 \mathrm{~b}$ is rejected.

Table 5. Study 2 - The mediation results.

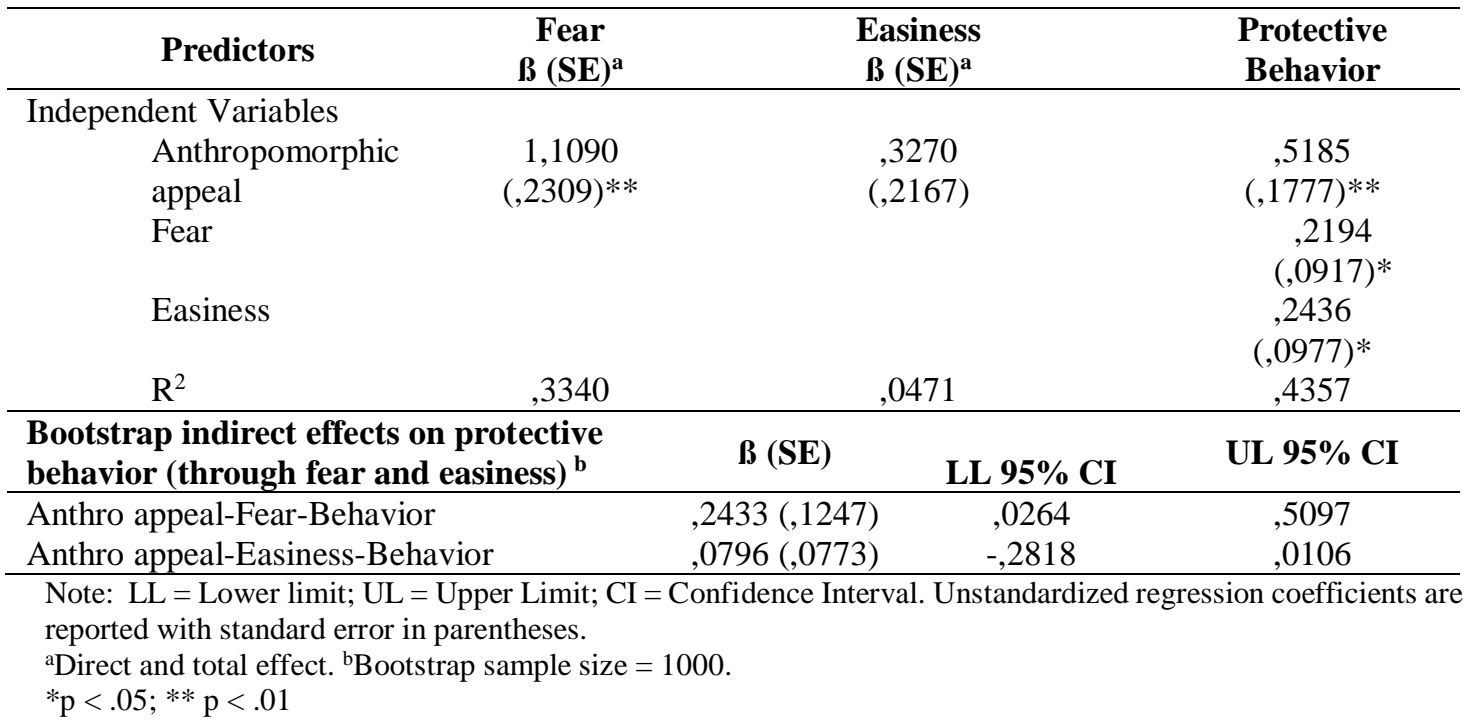

As we previously thought, the hypothesis $4 \mathrm{~b}$ is not supported because the appeals poster that serves as the stimulus contains content that is quite easy for consumers to understand. These results support the findings in Study 1 that the anthropomorphic approach makes it easier to understand the content that is difficult to understand.

\section{DISCUSSION}

Players in the service industry certainly want consumers to come and carry out health protocols in an orderly manner, keep their distance and wear masks. This research shows that the message about the coronavirus that is conveyed anthropomorphically makes it easier for consumers to understand the dangers and impacts of this virus on health, makes consumers feel more afraid, and perceives that this virus is stronger and has an impact on 
life when compared to viral messages as an object. Feelings of fear then influence protective behavior, keep your distance and wear a mask. This shows that emotions (fear) can play a positive role in protective behavior. Meanwhile, cognitively, the ease of understanding does not have a significant effect on protective behavior. Likewise, the perception that viruses have more power also does not affect protective behavior.

Study 2 confirms the results of Study 1 that conveying messages anthropomorphically can influence consumer behavior. Study 1 examined the basic concept and focused on the message content, whereas Study 2 focuses on its application in service facilities and focuses on how to convey the appeal message. Focusing on the content of the message, the stimulus in Study 1 was a full text containing an explanation of Covid 19, while in Study 2, the experimental stimulus was in the form of an image poster, with little text. Both studies show consistent results, namely communication to consumers using an anthropomorphic approach can have a positive effect on consumer behavior. These results are supported by previous studies on anthropomorphism in the marketing field (Aggarwal and McGill, 2007; Kim and McGill, 2011). It is also supported by previous studies on anthropomorphism in social marketing, namely that anthropomorphic messages have a positive effect on sustainability behavior (Tam et al., 2013; Tam, 2014; Laksmidewi and Soelasih, 2018; Laksmidewi and Soelasih, 2019). This study was adapted from The (Khoa et al., 2020) and (Wan and Cowan, 2020). Not all variables were examined, but the results of this study support their research.

(Tam, 2014) stated that a message will be able to persuade consumers if it is compatible with consumer motivation. People tend to have effectance motivation, which is the motivation to be able to predict their erratic environment (Epley et al., 2007). In the situation of the Covid-19 pandemic, consumers face a situation of uncertainty, and consumers are motivated to be able to master it. Anthropomorphism can fulfil the need for effectance motivation (Epley et al., 2007; Waytz et al., 2010). Besides fulfilling the motivation to socialize, it also makes anthropomorphic messages effective. According to the Three Factor Theory of Anthropomorphism by (Epley et al., 2007), people have a need to socialize with agents. In this case, the Coronavirus becomes an agent that consumers want to know, so illustrating it is human-like makes it easier to recognize.

This research result is supported by (Huang, 2020), namely that fear, which is a negative emotion, does not always have a bad impact, but can encourage prevention efforts. In this pandemic situation, consumers feel that their lives are threatened, afraid, and this affects their behavior (Dedeoglu and Ventura, 2017). This research shows that the anthropomorphic message of the coronavirus makes consumers feel more threatened, fear, and influences protective behavior by maintaining distance and wearing masks. Emotional Appeal is commonly used by marketers in their promotional advertisements to influence consumers to buy their products (Sobol and Sobol, 2017). In a situation of natural disasters, feelings of fear affect shopping behavior (Larson and Shin, 2018). In this study, messages that educate consumers about Covid-19 cause negative emotions, namely fear, which ultimately affects protective behavior in service facilities. Although the messages conveyed anthropomorphically make understanding easier, and increase the perception of power, this does not sufficiently influence behavior.

Anthropomorphizing objects will make a person better understand objects, reduce uncertainty, and increase predictive ability about objects (Epley et al., 2017; Waytz et al., 2010; Wan and Chen, 2021). In this study with an anthropomorphic approach, participants 
become more aware of the Coronavirus and make it better able to predict its impact on themselves. This makes the power higher in the anthropomorphism group, people feel they can predict the power of Covid-19. In a situation like this pandemic, hearing the news and statistics on Covid-19 sufferers makes people feel powerless. People with low power, looking at anthropomorphic objects will create the perception that these objects are high risk (Kim and McGill, 2011). Likewise in this research, the participants may have a highrisk perception of the message content, or in this case, anthropomorphic messages have a positive effect on power.

In terms of technological machine services such as robots, anthropomorphism can reduce customer dissatisfaction with service, and make customers want to continue using these machines (Fan et al., 2020). This research shows that direct anthropomorphic messages have no significant effect on protective behavior in service facilities. Through three mediating variables, namely fear, power, and easiness, only fear has a significant mediation. From this, it can be concluded that protective behavior can be influenced by anthropomorphic messages through the feelings of fear they cause. (Unlike Fan et al., 2020), protective behavior occurs because consumers want to avoid these anthropomorphic objects.

This research has managerial implications for service companies that want to give messages to their customers to come to service facilities while still being disciplined in paying attention to health protocols. As is the case with (Golossenko et al., 2020), providing appearance, moral virtue, cognitive experience, and conscious emotionality will create a brand anthropomorphism. Although this research does not lead to brands, the stories built in the research stimulus using human traits, personality, emotions, and actions can increase anthropomorphism. As has been studied in previous studies that anthropomorphic messages have been shown to have a significant effect on consumer behavior, not only shopping behavior, but also social behavior such as the intention to recycle (Han et al., 2019), and the intention to donate to environmental problems (Laksmidewi and Soelasih, 2018).

\section{CONCLUSION}

The service industry and its consumers need to adapt to the pandemic situation and prepare for post-pandemic. Enforcement of health protocols is necessary; therefore, it needs discipline from consumers to comply. The results of Study 1 indicate that anthropomorphic messages have a direct effect on protective behavior. Mediation testing shows that fear can be a significant mediator, not easiness and power, although anthropomorphic messages can create significant ease of understanding and higher perceptions of power. While Study 1 examines the basic concept of anthropomorphism in text messages that are difficult for ordinary people to understand, Study 2 is more focused on testing this anthropomorphic concept in its application in the service industry. Supporting the results of Study 1, fear also becomes a significant mediator of the effect of anthropomorphic appeals on protective behavior as shown in Study 2.

This study provides an insight into how to influence consumer health-protective behavior, namely through an anthropomorphic approach mediated by the emotional variable (fear). Understanding the impact of the coronavirus that is conveyed anthropomorphically, using human characteristics, namely character, and intention, can make consumers feel fear, and then make them intend to behave protectively in-service facilities. This study shows that emotional variables are more effective in influencing behavior than cognitive variables 
such as ease of understanding. Although consumers become easier to understand, it does not significantly affect behavior.

The managerial implications of the results of this study are the health protocol appeals can be delivered using an anthropomorphic approach. The persuasion effect causes negative emotions (fear) which has a positive effect, namely the intention to protect consumers themselves from being infected with the Coronavirus. For messages that are difficult, the way of delivery with text can clarify understanding, while messages that are familiar to consumers can use illustration images.

This research only consists of two study, so for future research, further studies can be carried out, for example by making anthropomorphic service promotion messages with the theme of mask wearing, or other health protocols. This study uses an experimental method with young consumer participants. Future research can use field experiments, or surveys, with respondents in other age groups. In line with the results of this study, themes that trigger emotions or consumer feelings are preferable, because they will affect protective behavior. If in this study anthropomorphic messages are directed at triggering negative emotions, namely fear, then in future studies, message stimuli that trigger other negative emotions can be tried, such as anxiety, anger, frustration, sadness, hopelessness, loneliness, panic, regret, annoyance, and shock. (Huang, 2020). Or vice versa, try the effect of messages that trigger positive emotions to see if it is more effective than negative emotions.

\section{REFERENCES}

Aggarwal, P., and Mcgill, A. L. (2007). Is that car smiling at me? Schema congruity as a basis for evaluating anthropomorphized products. Journal of Consumer Research, 34(4), 468-479. https://doi.org/10.1086/518544.

Ali, F., Dogan, S., Amin, M., Hussain, K., and Ryu, K. (2021). Brand anthropomorphism, love and defense: does attitude towards social distancing matter? Service Industries Journal, 41(1-2), 58-83. https://doi.org/10.1080/02642069.2020.1867542.

Anderson, C., and Galinsky A.D. (2006). Power, optimism, and risk-taking. European Journal of Social Psychology, 36, 511-536.

Dedeoglu A.O., Ventura K. (2017) Consumer Responses to Swine Flu (H1N1) Threat and Fear Arousing Communications: The Case of Turkey. In: Campbell C.L. (eds) The Customer is NOT Always Right? Marketing Orientations in a Dynamic Business World. Developments in Marketing Science: Proceedings of the Academy of Marketing Science. Springer, Cham. https://doi.org/10.1007/978-3-319-50008-9_66.

DiSalvo, C., and Gemperle, F. (2003). From Seduction to Fulfillment: The Use of Anthropomorphic Form in Design. Proceedings of the International Conference on Designing Pleasurable Products and Interfaces, 67-72.

Epley, N., Waytz, A., and Cacioppo, J.T. (2007). On seeing human: A three-factor theory of anthropomorphism. Psychological Review, 114 (4), 864-886.

Epley N., Waytz A., Akalis S., and Cacioppo J.T.(2008). When we need a human: motivational determinants of anthropomorphism. Social Cognition, 26(2), 143-155.

Faizan Ali, Seden Dogan, Muslim Amin, Kashif Hussain and Kisang Ryu (2021). Brand anthropomorphism, love and defense: does attitude towards social distancing matter? The Service Industries Journal, 41:1-2, 58-83, DOI: 10.1080/02642069.2020.1867542. 
Fan, A., Wu, L. (Laurie), Miao, L., and Mattila, A. S. (2020). When does technology anthropomorphism help alleviate customer dissatisfaction after a service failure? The moderating role of consumer technology self-efficacy and interdependent selfconstrual. Journal of Hospitality Marketing \& Management, 29(3), 269-290. https://doi.org/10.1080/19368623.2019.1639095.

Han, N. R., Baek, T. H., Yoon, S., and Kim, Y. (2019). Is that coffee mug smiling at me? How anthropomorphism impacts the effectiveness of desirability vs. feasibility appeals in sustainability advertising. Journal of Retailing and Consumer Services, 51(January), 352-361. https://doi.org/10.1016/j.jretconser.2019.06.020.

Hayes, A.F. (2017). Introduction to mediation, moderation, and conditional process analysis. A regression-based approach. The Guilford Press. New York.

Hoh Teck Ling, G. and Mee Chyong Ho, C (2020). Effects of the Coronavirus (COVID-19) Pandemic on Social Behaviours: From a Social Dilemma Perspective. Technium Social Sciences Journal, 7, 312-320.

Huang, P. H. (2020). Pandemic Emotions: The Good, the Bad, and the Unconscious Implications for Public Health, Financial Economics, Law, and Leadership. Colorado Law, 20. https://papers.ssrn.com/sol3/Papers.cfm?abstract id=3575101.

https://databoks.katadata.co.id/datapublish/2021/03/07/jutaan-orang-belum-patuhprotokol-kesehatan-di-fasilitas-umum.

https://edition.cnn.com/2020/03/26/business/social-distancing-brand-logoscoronavirus/index.html.

Golossenko, A., Pillai, K. G., and Aroean, L. (2020). Seeing brands as humans: Development and validation of a brand anthropomorphism scale. International Journal of Research in Marketing, 37(4), 737-755. https://doi.org/10.1016/j.ijresmar.2020.02.007.

Guthrie, S. (1995). Faces in the clouds : A new theory of religion. Oxford University Press.

Joubert, M. and Wasserman, H. (2020). 'Spikey blobs with evil grins: understanding portrayals of the coronavirus in South African newspaper cartoons in relation to the public communication of science'. Journal of Science and Communication, 19 (07), A08, 1-26. https://doi.org/10.22323/2.19070208.

Kamil, P.I., Susianto, H., Purwandana, D and Ariefiandy, A. (2020) Anthropomorphic and factual approaches in Komodo dragon conservation awareness program for elementary school students: Initial study, Applied Environmental Education \& Communication, 19:3, 225-237, DOI: 10.1080/1533015X.2019.1582374.

Kutschera, U. (2020). The Coronavirus as a Personalized Enemy of Mankind The Coronavirus as a Personalized Enemy of Mankind. April.

Kim, S., and McGill, A. (2011). Gaming with Mr. Slot or Gaming the Slot Machine? Power, Anthropomorphism, and Risk Perception. Journal of Consumer Research, 38 (1), 94 107.

Laksmidewi, D., and Soelasih, Y. (2018). Brand action for environmental sustainability: Is brand a hero or a caregiver? Pertanika Journal of Social Sciences and Humanities, 26(T), 183-196.

Laksmidewi, D., and Soelasih, Y. (2019). Anthropomorphic green advertising: How to enhance consumers' environmental concern. DLSU Business and Economics Review, 29(1), 72-84. 
Larson, L. R. L., and Shin, H. (2018). Fear During Natural Disaster: Its Impact on Perceptions of Shopping Convenience and Shopping Behavior. Services Marketing Quarterly, 39(4), 293-309. https://doi.org/10.1080/15332969.2018.1514795.

Mat Dawi, N., Namazi, H., Hwang, H. J., Ismail, S., Maresova, P., and Krejcar, O. (2021). Attitude Toward Protective Behavior Engagement During COVID-19 Pandemic in Malaysia: The Role of E-government and Social Media. Frontiers in Public Health, 9(March), 1-8. https://doi.org/10.3389/fpubh.2021.609716.

May, F., and Monga, A. (2014). When time has a will of its own, the powerless don't have the will to wait: Anthropomorphism of time can decrease patience. Journal of Consumer Research, 40(5), 924-942. https://doi.org/10.1086/673384.

Shao, X., Jeong, E. H., Jang, S. C. (Shawn), and Xu, Y. (2020). Mr. Potato Head fights food waste: The effect of anthropomorphism in promoting ugly food. International Journal of Hospitality Management, 89(February). https://doi.org/10.1016/j.ijhm.2020.102521.

Sheehan, B., Jin, H. S., and Gottlieb, U. (2020). Customer service chatbots: Anthropomorphism and adoption. 115(February 2019), 14-24. https://doi.org/10.1016/j.jbusres.2020.04.030.

Sobol, K., and Sobol, K. (2017). The Power of Negative Visualizations : When Fear Appeals Motivate Consumer Behavior. 45, 892-893.

Tam, K. P., Lee, S. L., and Chao, M. M. (2013). Saving Mr. Nature: Anthropomorphism enhances connectedness to and protectiveness toward nature. Journal of Experimental Social Psychology, 49(3), 514-521. https://doi.org/10.1016/j.jesp.2013.02.001.

Tam, K.-P. (2014). Are anthropomorphic persuasive appeals effective? The role of the recipient's motivations. British Journal of Social Psychology, 54(1), 187200. doi:10.1111/bjso.12076.

The Khoa, D., Wang, C. Y., and Guchait, P. (2021). Using regulatory focus to encourage physical distancing in services: when fear helps to deal with Mr. Deadly COVID-19. Service Industries Journal, 41(1-2), 32-57. https://doi.org/10.1080/02642069.2020.1831477.

Wan, J., Kulow, K., and Cowan, K. (2020). It's Alive! Increasing Protective Action Against the Coronavirus Through Anthropomorphism and Construal. Journal of the Association for Consumer Research. doi:10.1086/711849.

Waytz A., Morewedge C.K., Epley N., Monteleone G., Gao J.H., Cacioppo J.T. (2010). Making Sense by Making Sentient: Effectance Motivation Increases Athropomorphism. Journal of Personality and Social Psychology. 1-27.

Wan, E. W., and Chen, R. P. (2021). Anthropomorphism and object attachment. Current Opinion in Psychology, 39, 88-93. https://doi.org/10.1016/j.copsyc.2020.08.009.

Wu, E. C., and Cutright, K. M. (2018). In god's hands: How reminders of god dampen the effectiveness of fear appeals. Journal of Marketing Research, 55(1), 119-131. https://doi.org/10.1509/jmr.15.0246.

Zhou, X., Kim, S., and Wang, L. (2019). Money helps when money feels: Money anthropomorphism increases charitable giving. Journal of Consumer Research, 45(5), 953-972. https://doi.org/10.1093/jcr/ucy012.

Zhu, M., Billeter, D.M., and Inman, J.J. (2012). The double-edged sword of signaling effectiveness: when salient cues curb post-purchase consumption. Journal of Marketing Research, 49(1), 26-38. 